\title{
Still the Stranger at the Feast? Ideology and the Study of Twentieth Century British Politics
}

\begin{abstract}
This article explores the way in which scholars of twentieth-century British politics have engaged with the concept of ideology. It begins by revisiting Michael Freeden's seminal intervention on the subject before going on to assess the way in which recent work has challenged, and indeed preserved, older assumptions about the nature and function of political ideas. In doing so, it pursues two objectives: it seeks to demonstrate the consequences of regarding ideas as a significant feature of twentieth-century politics, and it attempts to encourage a more vibrant dialogue between historians and other disciplines that are contributing to the field of ideology studies.
\end{abstract}

In the inaugural issue of Twentieth Century British History, Michael Freeden discussed the way in which historians of modern British politics had engaged with the concept of ideology. His principal observation was that many accounts had devoted insufficient attention to ideas. Not only had they assumed that ideology was an eliminable feature of political systems, but they had also suggested that ideas were the epiphenomena of other social and economic forces. Ideology, Freeden concluded, was often the 'the stranger at the feast' ${ }^{1}{ }^{1}$ This article revisits Freeden's intervention and explores how recent scholarship has engaged with political ideology. In doing so, it pursues two objectives. First, it attempts to expose what is at stake when ideology is awarded an adequate status within understandings of modern British politics. And second, it encourages a more vibrant dialogue between historians and other disciplines that are contributing to the field of ideology studies.

Freeden's intervention can be summarised briefly. In it, Freeden identified three problematic assumptions that had concealed ideology from the historian's gaze. The first concerned the way in which ideology had been defined. Within many accounts, Freeden noted, it was assumed that ideology emerged from specialised, doctrinaire forms of thought and was produced by political elites. This notion was problematic in two respects: it invited the assumption that ideology was an 
eliminable feature of political systems, and it concealed 'the connections between grass-roots thinking and feeling and more highly articulated and structured expressions of political thought'. ${ }^{2}$

Freeden also challenged the assumption that ideas were epiphenomena that reflected 'real' social and economic relations. This conception of ideology had been inherited from the ontology of an earlier kind of Marxist analysis, and its implications were significant. As well as encouraging historians to regard ideas as being causally insignificant, it had also led some scholars to draw a distinction between 'practical' and 'ideological' modes of thought. Historians were thus disposed to regard ideology as an optional feature of politics whose influence was variable. Yet these assumptions were problematic, for they failed to acknowledge that even the most non-doctrinaire statements were imbued with ideological assumptions and values. ${ }^{3}$

Finally, Freeden raised concerns about the way that historians had classified political ideologies. Too often, Freeden claimed, it was assumed that Britain's liberal, socialist and conservative traditions were distinctive formations whose boundaries were clearly defined, and as a consequence, historians had tended to attribute particular policy innovations to the direct influence of these discrete ideologies. Freeden demonstrated the deficiency of these conclusions by drawing attention to the permeable boundaries that existed between different ideologies. Because they share common concepts, different ideologies, he argued, necessarily overlap. And as they meet the demands of new historical contexts, they often colonise the conceptual terrain that had once been occupied by rival bodies of thought. Accordingly, Freeden advocated an approach to the study of ideologies that acknowledged their fluid conceptual boundaries and accommodated their logical contradictions. Evident here were insights that came to inform the conceptual model of studying ideologies that Freeden would later develop. ${ }^{4}$

Freeden concluded his analysis by drawing attention to the virtues of methodological pluralism. A range of analytical tools, he argued, would be necessary to illuminate the different features of political ideologies and the way they functioned within different social contexts.

\section{History and the 'Ideational Turn'}

In recent decades, scholars in a number of disciplines have devoted greater attention to political ideas. Indeed some writers have made reference to an 
'ideational turn' that has transformed the way that political systems are understood. ${ }^{5}$ This shift can, in part, be attributed to the slow decline of older explanatory frameworks that defined ideas as an epiphenomena of political life. But of equal significance has been the influence of new developments in political philosophy and social science that have opened up new ways of understanding human consciousness. ${ }^{6}$ This ideational turn has been most visible in the field of political analysis, where new research programmes have emerged that are concerned, above all else, with determining the relationship between ideas and political change. ${ }^{7}$ But historians, including many who are concerned with the history of modern Britain, have also reconsidered the way that they engage with ideas. Three general developments can be identified. First, it has become common for historians of twentieth-century Britain to suggest that socio-economic phenomena are discursively mediated. ${ }^{8}$ Post-war economic decline, for instance, is now conceived as a phenomenon whose meanings were constructed as much by commentators and politicians as they were by concrete material forces. ${ }^{9}$ And the economic crises that have been associated with episodes of political change have come to be regarded as the subjects of narratives that had no necessary correspondence with external realities. ${ }^{10}$ Not all of the scholars who have contributed to this development have made direct engagements with the concept of ideology. Indeed many, particularly those under the influence of Foucauldian ideas, have been reluctant to employ this category. ${ }^{11}$ But because their studies often make reference to acts of discursive narration that are necessarily attempts to control the meanings of a particular event or phenomenon, their studies have nonetheless opened up analytical space that ideology can occupy.

Second, historians of modern Britain have begun to award greater causal significance to political ideas. Challenging those models of political behaviour that tended to regard material interests as being constitutive of political ideas, they have illuminated the way in which the latter have often mediated the former. Some historians of 1980s Britain, for instance, have disputed the argument that Thatcherism's ascendency followed from social and economic changes whose consequences were fixed. Instead, they argue, the interests of electors, financial institutions and others actors were determined by discursive interventions that were ideological in nature. ${ }^{12}$ In part, this shift can be attributed to the social constructivist models of behaviour that have been developed by Peter Hall and Mark Blyth. ${ }^{13}$ These models, which have been sensitive to the importance of history to political processes, have broken decisively with the ontology of rational choice theory and have awarded ideas a central role in determining political 
conduct. They have also reconceptualised the nature of ideological competition. Whereas older accounts tended to regard the activities of elites and policy-makers as being of central importance, these models award greater significance to the broader social arena in which these actors are located. Policy-makers and other state actors, it is argued, operate within a discursive environment that is shaped by wider social forces, such that the conduct of the former can only be adequately understood in the context of the latter. ${ }^{14}$

Third, historians have become more interested in the relationship between formal, structured patterns of high political thought and the social conditions from which they emerged. No longer are Britain's traditions of liberalism, social democracy and conservatism understood as the products of elite thinking that have been imposed upon the British state by elites. Rather, they are more likely to be conceived as social formations that have been shaped by cultural change. Here, the influence of the 'new political history' has been particularly influential. ${ }^{15}$ Contributors to this tradition have sought to locate party politics within much broader social and cultural contexts, and in doing so, they have made two contributions to the way political ideologies are understood. First, they have demonstrated that political ideologies are often social constructs that operate within a discursive context that is shaped by vernacular forms of thinking. And second, they have exposed the vast range of institutions and groups that have shaped political contestation within the parliamentary arena. ${ }^{16}$

While some scholars have explored the complexity of the major ideologies of British politics, others have drawn attention to the formations that competed with them for authority. Feminism, ecologism and other ideologies have thus been recognised as important ideational systems that have done much to shape Britain's political landscape. ${ }^{17}$ And it has also become more common for historians to regard non-state actors as important producers of political ideas. The chief consequence of these developments has been to disrupt the view that British politics was marked by a dispute between three major ideologies whose character was determined by a small number of political elites.

Together, these three developments have done much to marginalise many of the assumptions that Michael Freeden described in his aforementioned intervention. Not only have they exposed the deficiency of older explanatory frameworks that denied ideas a significant causal role, but they have also displaced the negative definition of ideology that concealed many formations from the historian's gaze. But if the more problematic assumptions that Freeden described have been challenged, it is possible to identify the emergence of others 
that continue to obscure the central role that ideas have played in British political life. One of the most notable concerns the ontological status that is awarded to ideology. As we have seen, it is now less common for historians to define ideology as false consciousness. What can be detected, however, are instances where ideology is defined in relation to 'scientific' or 'objective' forms of knowledge. ${ }^{18}$ Consider, for instance, the tendency for histories of the Labour party to describe Harold Wilson as a non-ideological figure who was concerned, above all else, with practical questions. ${ }^{19}$ At one level, these formulations serve a necessary function. Indeed they draw a distinction between different kinds of political thinking that are informed by different epistemological beliefs. What they also threaten to do, however, is to define ideology as an eliminable feature of political life. For it follows that there are forms of social signification which are free of ideology and which are capable of representing an external reality in its true form. It would be more appropriate, then, to draw a distinction between rationalist and non-rationalist ideologies. Such a distinction acknowledges that different ideologies are informed by different epistemologies, but it does not invite the notion that some are less ideological than others.

The notion that ideology is necessarily doctrinaire also conceals the ideological character of 'non-ideological' statements. As Ewen Green noted in his study of Conservatism, such statements are ideological acts. ${ }^{20}$ Not only are they informed by certain epistemological assumptions, but they also emerge from a particular understanding of appropriate political action. And once this is acknowledged, even the most disinterested and non-doctrinaire statements come to acquire ideological meanings. It thus becomes necessary to recognise the vast range of institutions and individuals who have contributed to the production and reproduction of ideologies. Yet even recent studies of Britain's political ideologies tend to privilege the thought and practices of those individuals who have been engaged in particular kinds of thinking. Indeed those individuals who produced elaborate and coherent statements of political thought are often conceived as the most influential producers of ideas.

Because some scholars have reproduced the notion that ideologies are doctrinaire, they have also implied that ideology is a feature of political life whose presence is variable. Yet this formulation invites some problematic historical assumptions. Chief amongst them is the idea that some historical periods are more ideological than others. As Freeden noted, this conceals the way in which pragmatism and agreement are often the product of ideological assumptions and beliefs, and it also encourages the idea that some forms of political practice can 
be understood without making reference to the thought that informs them. Yet some narratives of modern Britain have nonetheless reproduced it. Consider, for instance, how some accounts describe Britain's post-war politics. While the 1950s and 1960s were decades marked by the relative absence of ideology, the 1970s, they argue, was punctuated by fervent ideological debate. It may be necessary, then, for historians to reconsider the relationship between ideas and political conflict. The presence of the latter does not preclude the absence of the former. And as Freeden once noted, it may be that periods of relative political calm are the product of an ideology's ability to secure hegemony. ${ }^{21}$

The tendency to regard ideology as a doctrinaire form of knowledge is, of course, a more general phenomenon. Raymond Williams once observed that since its inception, the 'limiting condition' of the concept of ideology was that it tended to restrict "processes of meaning and valuation to formed, separable "ideas" or "theories". ${ }^{22}$ But if it would be inappropriate to blame historians for the reproduction of a narrow definition of ideology, it is also the case that they are well-positioned to expose its deficiencies. Not only can they reveal the contingent and thus ideological nature of the most benign and enduring features of British political life, but they can also untangle the complex ideological contestation that informs the most ordinary political practices.

\section{Drawing Boundaries}

In his intervention, Freeden was critical of the 'simple tagging' method that had often been employed to determine the character of Britain's ideological traditions. Too often, he argued, scholars had operated on the assumption that these formations had 'mutually exclusive contours' and had, in turn, sought to identify the single concept or belief that defined them. ${ }^{23}$ Continuing his analysis, Freeden suggested that once attention was drawn towards the conceptual content of these formations, it became apparent that such notions were problematic. Ideologies were thus described as 'complex structures that display a number of configurations, linked by family resemblances, but having components shared with other ideologies'. ${ }^{24}$

Freeden's morphological conception of ideologies has been taken up by a number of studies, and it is now common for general accounts to acknowledge the blurred conceptual barriers that separated Britain's progressive ideologies. ${ }^{25}$ But the full implications of Freeden's work have not yet been acknowledged, and it is still possible to locate some accounts that categorise ideologies in 
problematic ways. Here, it is useful to make particular reference to the historiography of British Conservatism. Recent studies of this tradition have disputed the argument that Conservatism is a 'non-ideological' disposition, and as a result, we are now equipped with a number of detailed and illuminating descriptions of the ideas and beliefs that informed the thought and practices of the Conservative party. ${ }^{26}$ But some of these accounts, in their efforts to identify the organising principle of Conservatism, have produced some problematic propositions. Perhaps the most troubling is the suggestion that Conservatism is a philosophy of inequality. This argument, as I have argued elsewhere, fails to acknowledge the epistemology that informs conservative thinking. ${ }^{27}$ Because they are suspicious of rationalism, conservatives are unwilling to suggest that any particular concept or arrangement is of universal value. And as a result, their willingness to endorse any concepts or arrangements is necessarily contingent and mediated by experience. To suggest that a commitment to preserving inequality is their core belief is thus to ignore conservatism's distinctive morphology. Inequality, like any other substantive concept within the conservative lexicon, is, in theory at least, eliminable.

The search for Conservatism's conceptual core has not only obscured the peculiar character of Conservatism; it has also concealed its remarkable flexibility. Because there are no logical constraints on what social and political arrangements a Conservative can endorse, they are prone to modifying their beliefs in response to novel circumstances. Indeed, as one leading Conservative wrote in 1947, they see "nothing immoral or even eccentric in "catching the Whigs bathing and walking away with their clothes"'. ${ }^{28}$ It is unsurprising, then, that Conservatives have both defended and deplored the state and have celebrated and challenged the virtues of free enterprise. Yet some studies, in their efforts to identify consistent patterns within Conservatives discourses, have threatened to conceal the malleability of Conservatives' programmatic commitments. Some accounts, for instance, regard Margaret Thatcher as an ideologue who, in her efforts to anchor the Conservative party to a monetarist economic strategy, departed from the conservative tradition. ${ }^{29}$ And others seize upon certain arrangements, such as private property relations, and describe them as universal features of any Conservative vision. ${ }^{30}$

A related point can be made regarding the way in which Britain's major ideologies are situated in relation to one other. Taking up the insights of Freeden and other scholars, historians have developed a sensitivity to the way in which Britain's liberal and social democratic formations have over-lapped. ${ }^{31}$ Jackson's 
impressive study of socialist through has, for instance, done much to reveal the enduring influence that liberal ideas exerted upon the thinking of post-war social democrats. ${ }^{32}$ It is more difficult, however, to locate discussion of the relationship between Conservatism and other ideologies. ${ }^{33}$ And this omission is significant, since it exposes a failure to adequately recognise the way in which rival ideologies have determined the conceptual content of Conservatism. In a vital sense, Conservatism is a reflective ideology. ${ }^{34}$ It does not generate its own meanings; rather, it acquires them from the rival ideologies that threaten to dismantle the harmony of the organic social order. Indeed it could be claimed that the true task of conservatism is a profoundly negative one. Instead of seeking to construct a vision of the future that is informed by its rational enquiry, it aims to counter those concepts and argument that are expounded by whatever progressive ideology it encounters. ${ }^{35}$ The implications of this insight are numerous. Most importantly, it invites the notion that Conservatism cannot be fully understood unless its history is situated alongside those of Britain's progressive traditions. It would be useful, then, for future studies to devote greater attention to the way in which Conservatives have understood, and responded to, the ideological innovations of their progressive opponents. Such work would not only expose the contingent nature of the conservatives' conceptual lexicon; it would marginalise the assumption that there is an 'authentic' variant of conservatism that can be employed as a barometer to judge others.

Finally, it must be noted that conservative concepts and ideas have not been the exclusive property of institutions and individuals that choose to refer to themselves as conservatives. Consider, for instance, the conservative tendency to regard societies as organic wholes that are comprised of interdependent components. ${ }^{36}$ This notion is such a ubiquitous feature of British Conservative discourse that it is tempting to regard it as a proprietary feature of its conceptual architecture. But an enquiry into rival ideologies reveals that it has often informed the thinking of Conservatives' political opponents. One of the most important statements of post-war social democratic thought, Anthony Crosland's The Future of Socialism, thus contained the following statement:

The fact is that a society like ours is an organic unity ... one so highly organised and interdependent between its various parts, resting as it does on a balance of tensions, thrusts, and stresses, that intervention at one point will have effects at numerous and often unexpected other points. One therefore cannot give it a shock of 
more than a certain violence without the risk of damage to the entire structure. $^{37}$

It would be absurd, of course, to suggest that Crosland was a conservative. Many of his core beliefs, namely his belief in the virtues of social equality, were at odds with conservatives' epistemological views. What this statement demonstrates, however, is that conservative concepts could traverse the boundaries between parliamentary parties.

This insight has wider implications for our understanding of British politics. Most importantly, it invites us to reconsider the nature of policy change. As Freeden noted, it was once common for historians to assume that particular policies could be located neatly within Britain's distinctive ideological traditions and that their fortunes were tied to the relative health of these formations. Once we acknowledge that the conceptual architecture of these traditions has often over-lapped, this assumption becomes problematic. Indeed it may be more appropriate to suggest that certain policy proposals and ideas gained salience because they were commensurable with common features of competing ideological formations. Recent studies on the influence of Keynes' economic ideas have certainly invited conclusions of this kind. ${ }^{38}$ Many of Keynes' ideas were incompatible beliefs that informed Labour and Conservative thought. Yet both parties were able to endorse some Keynesian propositions because they were commensurable with their common hostility to classical liberal ideas and their shared commitment to full employment.

\section{The Causal Role of Ideas}

Until recently, it was common for historians of modern Britain to regard ideology as an epiphenomena of political change. Even scholars who attempted to draw attention to the causal role of ideas often conceptualised them in ways that concealed their causal significance. In part, this tendency followed from the assumption that other features of political systems, such as interests, were external to ideological influence. Thus Anthony Seldon, in a discussion of the role that ideas played in determining post-war public policy, suggested that 'ideas are not enough'. Only when ideas were able to correspond with the interests of important groups, he argued, could they exert a substantial influence upon political conduct. Indeed he concluded that 'what is surprising about the impact 
of ideas on post-war British history is just how limited rather than great their impact has been. ${ }^{39}$ In recent decades, many studies have challenged these formulations. Not only have they exposed the way in which ideas mediate the interests of actors, but they have also drawn attention to the way in which events are understood through discursive frameworks. ${ }^{40}$ To some extent, these innovations have followed from the slow and uneven dissolution of older historiographical traditions that awarded causal primacy to extra-ideological phenomena. But of equal significance has been the proliferation of new interpretive frameworks that have compelled historians to reconsider the relationship between ideas and other features of political systems. Particular attention can be drawn to the Kuhnian models of learning that have been advanced by Peter Hall and others. ${ }^{41}$ According to these models, actors operate within paradigms of knowledge that condition their understanding of the social context that they operate within. But these paradigms can be disrupted when events contravene their logic, and in such instances, new ideas can reshape the political terrain and influence public policy. ${ }^{42}$

By awarding ideas a crucial role in determining the outcomes of political crises, these models have done much to place ideology at the centre of political systems. And in recent years, some scholars of modern Britain have employed them to develop a better understanding of the conditions in which certain political ideas took root. It may be necessary, however, for historians to refine their analytical assumptions that inform these explanatory systems; for some of these assumptions, as recent studies have demonstrated, present some conceptual problems. Perhaps the most significant of these concerns the notion that ideas are only influential when exogenous forces disrupt prevailing patterns of thought. This proposition introduces an inconsistent ontology; for according to its logic, ideas can be both constitutive and auxiliary forces. ${ }^{43}$ In a sense, then, they preserve what Freeden termed the 'on-off switch' conception of ideology. ${ }^{44}$ On the one hand, they suggest that ideas are a priori determinants of political action. But on the other, they suggest that their influence is dependent on the presence of peculiar historical conditions.

The argument that uncertainty is an exceptional feature of political systems can also be challenged. This proposition, as Hay and Gofas have noted, follows from the assumption that relative political stability allows actors to gain more complete information about their social context. ${ }^{45}$ Yet such an assumption threatens to reintroduce the notion that ideologies are eliminable features of politics that only exist to fill information deficits that arise when the extra- 
ideological forces no longer supply actors with a clear understanding of their interests. It is thus difficult to reconcile with an ontology that takes as its startingpoint the constitutive role of ideas.

Kuhnian models also conceptualise ideas in a parochial manner. Indeed they tend to define ideas as cognitive road maps that can serve functional objectives rather than bodies of beliefs and values that can shape actors' moral positions. It is unsurprising, then, they have been employed to explain the influence of particular economic doctrines, such as Keynesianism and monetarism, at the expense of other ideologies that rendered them acceptable. Yet it is difficult to understand the ascendency of these doctrines unless that are understood as political, as well as economic, bodies of ideas. When Labour party figures engaged with Keynes' ideas in the 1940s and 1950s, they were not just concerned with the question of whether or not they were capable of achieving economic growth. They were also asking questions about the appropriate form of the state, the desirability of private consumption and the adequate distribution of wealth. ${ }^{46}$

Historians are well-placed to expose the limitations of the explanatory models that are being produced within social science. ${ }^{47}$ Armed with concrete empirical evidence of actors' thought and behaviour, they can test the assumptions that inform them. And with their knowledge of different historical contexts, they can also reveal the specificity of the ideas that political scientists are often preoccupied with. As yet, however, few historians have engaged with the literatures that have emerged from social science's 'historical turn'. In part, their reluctance to do so may stem from basic epistemological differences. But as political analysis takes its own historical turn, it may be that these differences become less pronounced in future decades. ${ }^{48}$

\section{Locating Ideology}

As well as drawing attention to the range of ideologies that have shaped the political terrain, historians of twentieth century Britain have also exposed the variety of institutions and groups that have contributed to the production of political ideas. Indeed think-tanks, pressure groups and debating societies have all been identified as institutions that have played an important role in producing and circulating ideas. ${ }^{49}$ In part, this development has followed from a reconsideration of the way in which ideas intervene in policy change. As Freeden noted, older accounts tended to award primacy to the influence of a small number 
of intellectuals who constructed formal and elaborate statements of political thought. Recent studies, by contrast, have suggested that the influence of particular ideas was often mediated by the institutions and individuals that articulated them to policy-makers and opinion-formers. Indeed their authors have demonstrated that these agents not only popularised the ideas of political elites; they also modified their meanings in order to maximise their appeal. ${ }^{50}$ But if we are now equipped with an awareness of the range of institutions that have been engaged in the production and consumption of political ideas, it is nonetheless the case that political parties tend to be regarded as the supreme arbiters of their value. Indeed most studies of Britain's liberal, socialist and conservative tradition tend to be anchored to the histories of Britain's main parties. And those ideologies that have been explored with greatest enthusiasm have often been those that political parties have taken up. Consider, for instance, the ideology of neoliberalism. Often, the rise of this ideology is tied to the history of the British Conservative party and, in particular, the actions of Keith Joseph and Margaret Thatcher. Yet this preoccupation with the Conservative party, as Ben Jackson has recently demonstrated, obscures the way in which neo-liberal ideas took up themes and ideas that could be found in progressive ideologies. ${ }^{51}$ It must also be noted that political parties have often been unreliable vehicles for the ideologies that they claim to represent.$^{52}$ In order to serve their electoral interests, they often advocate policies that contravene the logic of the ideological traditions that they are situated within. And because they are often pre-occupied with the immediate political and social contexts they inhabit, the relationship between their programmatic commitments and their core beliefs is often obscured. It is unsurprising, then, that the most elaborate and coherent statements of ideology are often produced by individuals and groups who are on the margins of their respective parties.$^{53}$ Political parties should thus be located within much broader communities of thought.

Historians could also do more to reveal the full range of concerns, values and beliefs that have been contained within political ideologies. Ideologies are not only clusters of concepts that are employed to describe a desirable social and political order. They are also comprised of epistemological beliefs, conceptions of temporality and understandings of space. ${ }^{54}$ As yet, however, historians of twentieth century Britain have not uncovered these kinds of beliefs. And such omissions are significant, for it is often these beliefs which determined the way in which political ideologies organised their conceptual architecture. In the case of Conservatism, for instance, the conceptual content of the ideology has always 
been mediated by its particular epistemology. Its adherents, by virtue of their limited conception of rationality, can only endorse a particular concept on a contingent basis. Indeed they must acknowledge that there are no concepts or arrangements that are universally desirable. If we are to better understand the nature of post-war Conservatism, then, it would be appropriate to examine not only the way in which Conservatives have modified their understandings of the state, the market and the social order, but to also study the epistemological views that informed such adjustments.

Drawing attention to these features of Britain's political ideologies may also reveal ideological patterns that are concealed by the surface forms of political discourses. Post-war social democrats like Anthony Crosland and Bryan Magee regarded the attainment of social equality as the central objective of socialist politics. Yet because they were suspicious of the idea of universal truth, they were reluctant to privilege a specific definition of equality that could inform a vision of the future. As Magee put it, 'the truth is [that] ... in human affairs we can see only a short way ahead, and even then our predictions are highly fallible and often wrong. ${ }^{55}$ What this example demonstrates is that the conceptual content of Britain's political ideologies can be apprehended differently once their epistemological foundations are uncovered.

\section{New Directions}

This is not the appropriate place to construct an alternative narrative of twentieth century British politics that places ideology at its core. It is instructive, however, to identify some ways in which our general understanding of the period might be modified if historians engaged with some of the propositions that have been outlined above. That is not to say, of course, that these propositions, which are informed by the author's own ontological assumptions and methodological preferences, should be universally endorsed. But by exposing their broader implications, we can evaluate what is at stake when we reconfigure our understanding of ideology.

In the first instance, we can establish the implications of regarding ideology as a ubiquitous feature of political life. Within some general narratives, this notion is resisted, for their authors tend to suggest that some periods of Britain's past were more ideological than others. Consider, for instance, the tendency to regard the 1950s as a decade when public policy was determined by pragmatic incrementalism rather than ideology. When a non-pejorative conception of 
ideology is adopted, these kinds of distinctions become untenable. Indeed it becomes necessary to acknowledge that periods of relative political stability may reflect the hegemony, rather than absence, of ideological thought practices. ${ }^{56} \mathrm{It}$ may become necessary, then, to construct new readings of post-1945 British politics. The alleged post-war settlement, rather than being understood as a stable system of pragmatic, consensual governance, could be reconceptualised as an ideological edifice that was forged on the basis of common assumptions about appropriate political conduct. ${ }^{57}$

Second, we can consider the implications of the morphological conception of ideologies that has been advocated by Freeden and others. This approach, as has been noted above, has informed a number of recent studies, but as yet, its full implications have not yet been acknowledged According to its logic, ideologies are thought practices that seek to attempt to fix the meanings of essentially contested concepts. Once we acknowledge this essential contestability, we are compelled to accept that no movement or group has exclusive control over the raw materials of political thinking. And in turn, it becomes necessary to adopt a more diachronic approach to the study of ideologies that is sensitive to the way in which different concepts have acquired and shed meanings over time. ${ }^{58}$

Engaging more fruitfully with a morphological approach to the study of ideologies would also reveal those concepts and ideas that have traversed the political divide but which have been anchored to different ideological formations. A provisional list might include those of meritocracy, efficiency, progress and public interest. All of these concepts have, of course, been integrated into accounts of twentieth century British politics. But there is a tendency to regard them as stable carriers of meaning that are employed by actors when historical conditions render those meanings politically useful. A morphological approach would instead place emphasis on the way in which actors have imbued concepts with different meanings in response to social, cultural and political change.

Being sensitive to a morphological conception of ideologies may also compel scholars to collapse some of the older categories that often inform general accounts of Britain's intellectual politics. Chief amongst them are those of 'left' and 'right', which, despite their resilience, often obscure the complexity of Britain's political ideologies. Not only do these categories encourage the student of ideology to privilege particular concepts at the expense of others, but they also invite the notion that centrist ideologies are synthetic entities that possess no distinctive conceptual resources. ${ }^{59}$ Once we acknowledge these problems, we may be compelled to reconsider many parties and individuals that have 
contributed to Britain's political development. Centrist parties, such as the shortlived Social Democratic Party, would be reconceptualised as institutions that possessed distinctive political ideas. ${ }^{60}$ 'Pragmatic' politicians would become recognised as the producers of important ideas about appropriate political conduct. And administrative institutions would no longer be understood as the opponents of ideology.

Finally, historians that are more sensitive to the complexity of political ideologies may develop a more pluralistic conception of ideological competition that took place in twentieth century Britain. Despite recent work that has sought to challenge epochal narratives, it remains common for particular decades to be associated with the dominance of clearly-defined ideologies. Future accounts, by contrast, may place emphasis on the ways in which ideologies absorb and shed concepts and ideas from their rivals in order to legitimate their core beliefs. In doing so, they may illuminate the hybridity of the political ideologies that have mediated political conduct.

\section{Conclusion}

Since Michael Freeden made his intervention in the first issue of Twentieth Century British History, historians of modern Britain have done much to integrate political ideologies into their accounts. And in doing so, they have marginalised the pejorative definition of the concept that was once predominant. Many of the analytical frameworks that have informed this turn to ideology have, however, contained propositions that obscure the full implications of taking ideology seriously. As well as retaining some of the reductivist meanings that were embedded within older definitions of ideology, they have also concealed the ubiquitous nature of ideological activity. If it is no longer appropriate, then, to regard ideology as the stranger at the feast, it remains true that historians have much to learn from innovations in the field of ideology studies.

What might be done to further advance historians' interest in, and understanding of, political ideologies? Three suggestions present themselves. First, it may be beneficial for historians of modern Britain to engage more directly

with the field of conceptual history. ${ }^{61}$ At its best, this research programme exposes the contingent and indeed ideological nature of the basic categories that structure political language. By drawing upon its insights, historians of modern Britain could thus illuminate those concepts that have traversed different 
ideologies and refine our understanding of the way in which political ideologies sought to contain their meanings.

Second, historians might need to engage in comparative approaches that bring Britain's ideological traditions into dialogue with those of other national contexts. Although we are now equipped with rich and sophisticated accounts of Britain's 'major' ideologies, little attempt has been made to place them in a relationship with comparable formations elsewhere. ${ }^{62}$ Doing so would, however, yield some instructive insights. Not only would it help to identify the peculiarity of the conceptual assemblages that British ideologies have constructed, but it would also illuminate the historical conditions that have allowed particular ideas to obtain influence in different geographical contexts.

Finally, and perhaps most importantly, it would be profitable for historians to acknowledge the distinctive contribution that they can make to the field of ideology studies. As the above discussion has demonstrated, political ideologies cannot be understood unless they are historicised. As yet, it has often been political theorists and social scientists that have taken up this task. But their analytical frameworks, which tend to tend to privilege synchronic rather than diachronic analysis, threaten to extract ideologies from their particular historical contexts. Equipped with empirical evidence and the ability to evaluate change over time, historians can expose the peculiarity of these contexts and, in turn, hold abstract models of ideational change to account.

Although the above discussion has been informed by the author's methodological preferences and ontological assumptions, it should not be read as a call for the primacy of a particular methodological framework. Methodological pluralism, as several writers have noted, is both necessary and desirable. And as Leader Maynard has observed, the interaction of different research programmes can be mutually beneficial. ${ }^{63}$ This methodological pluralism cannot be successful, however, unless different disciplines acknowledge the peculiar contributions that they can make to the field.

\section{Acknowledgements}

The author would like to thank Jörg Arnold for his comments on an earlier draft of this article. 


\section{Notes}

${ }^{1}$ M. Freeden,'The Stranger at the Feast: Ideology and Public Policy in Twentieth Century Britain', Twentieth Century British History, 1(1) (1990), pp. 9-34.

${ }^{2}$ Freeden, ibid., p. 14.

${ }^{3}$ Freeden, ibid., p. 10, p. 15.

${ }^{4}$ M. Freeden, Ideologies and Political Theory (Oxford: Clarendon, 1996).

${ }^{5}$ M. Blyth, '"Any More Bright Ideas?" The Ideational Turn of Comparative Political Economy', Comparative Politics, Vol. 2, No. 2 (1997), p. 229.

${ }^{6}$ C. Hay and D. Wincott, 'Structure, Agency and Historical Institutionalism', Political Studies, 46(5) (1998), pp. 951-957.

${ }^{7}$ For critical discussions of these programmes, see Andreas Gofas and Colin Hay (eds.), The Role of Ideas in Political Analysis (Oxford: Routledge, 2010).

${ }^{8}$ Here, the seminal work of Gareth Stedman Jones has exerted a strong influence. G.S. Jones, Languages of Class: Studies in English Working Class History, 1832-1982 (Cambridge: Cambridge University Press, 1983).

9 J. Tomlinson, The Politics of Decline (London: Routledge, 2000), p. 2; G. Ortolano, The Two Cultures Controversy: Science, Literature and Cultural Politics in Postwar Britain (Cambridge: Cambridge University Press, 2009).

${ }^{10}$ R. Saunders, "Crisis? What Crisis?" Thatcherism and the seventies' in B. Jackson and R. Saunders (eds.), Making Thatcher's Britain (Cambridge: Cambridge University Press, 2012), pp. 25-42.

${ }^{11}$ P. Rabinow (Ed.), The Foucault Reader (London: Penguin, 1984), pp. 60-61.

${ }^{12}$ J. Lawrence and F. Sutcliffe-Braithwaite, 'Thatcher and the Decline of Class Politics', Making Thatcher's Britain, op. cit, Ref. 10, p. 147.

${ }^{13}$ H. Pemberton, Policy Learning and British Governance in the 1960s (Basingstoke: Palgrave, 2004), p. 60; M. Matthijs, Ideas and Economic Crises in Britain from Attlee to Blair (London: Routledge, 2011). P. Hall, 'Policy paradigms, social learning and the state: the case of economic policymaking in Britain', Comparative Politics, Vol. 35 (1993), pp. 275-296. M. Blyth, Great Transformations: Economic Ideas and Institutional Change in the Twentieth-Century (Cambridge: Cambridge University Press, 2002).

${ }^{14}$ Hall, 'Policy paradigms', p. 289.

${ }^{15}$ Steven Fielding, 'Looking for the New Political History', Journal of Contemporary History, 42(3) (2007), pp. $515-524$

${ }^{16}$ L. Black, The Political Culture of the Left in Affluent Britain, 1951-64 (Basingstoke: Palgrave, 2004);

S. Fielding, The Labour Governments, 1964-70: Labour and Cultural Change (Manchester: Manchester University Press, 2003); L. Beers, Your Britain! Media and the Making of the Labour Party (Harvard:

Harvard University Press, 2010); D. Thackeray, Conservatism for the Democratic Age (Manchester: Manchester University Press, 2013); L. Robinson, “"Sometimes I Like to Stay in and Watch TV...” Kinnock's Labour Party and Media Culture', Twentieth Century British History, 22(3) (2011), pp. 354-390; G. Cohen and

L. Mates, 'Grassroots Conservatism in Post-War Britain: A View From the Bottom-Up', History, 98 (330) (2013), pp. 202-225.

17 S. Holton, Feminism and Democracy: Women's Suffrage and Reform Politics in Britain, 1900-1918 (Cambridge: Cambridge University Press, 2003). J. Gottlieb and R. Toye (eds.), The Aftermath of Suffrage: Women, Gender, and Politics in Britain, 1918-1945 (Basingstoke: Palgrave Macmillan, 2013). N. Carter, 'Party Politicization of the Environment in Britain', Party Politics, 12(6) (2006), pp. 747-767.

${ }^{18}$ For a brief but illuminating discussion of this usage, see R. Williams, Keywords (London: Fourth Estate, 2014), pp. 153-4.

${ }^{19}$ M. Pugh, Speak For Britain! A New History of the Labour Party (London: The Bodley Head, 2010). Also see C. Ellis, 'Letting it Slip: The Labour Party and the "Mystical Halo" of Nationalisation, 1951-64', Contemporary British History, Vol. 26, No. 1 (2012), p. 50. Ellis suggests that in the 1950s, the Labour party's 'stress on the pragmatic rather than the ideological aspects of nationalization ... diluted the connection to socialism.' Also see D. Wincott, 'Thatcher: Ideological or Pragmatic?', Contemporary Record, 4(2) (1990), pp. 26-28.

${ }^{20}$ E.H.H. Green, Ideologies of Conservatism (Oxford: Oxford University Press, 2002), p. 9.

${ }^{21}$ Freeden, 'Stranger at the Feast', op. cit, Ref. 1, p. 17.

${ }^{22}$ R. Williams, Marxism and Literature (Oxford: Oxford University Press, 1977), p. 70.

${ }^{23}$ Freeden, 'Stranger at the Feast', op. cit, Ref. 1, p. 12.

${ }^{24}$ Freeden, ibid., p. 31. Freeden, Ideologies, op. cit., Ref. 4. 
${ }^{25}$ D. Seawright, The British Conservative Party and One Nation Politics (London: Continuum, 2010), pp. 28-29. B. Jackson, Equality and the British Left (Manchester: Manchester University Press, 2005). M. Stears, 'Guild Socialism and Ideological Diversity on the British Left, 1914-1926', Journal of Political Ideologies, Vol. 3, No. 3 (1998), pp. 289-306.

${ }^{26}$ P. Dorey, British Conservatism: The Politics and Philosophy of Inequality (London: I.B. Tauris, 2010). K. Hickson (Ed.), The Political Thought of the Conservative Party since 1945 (Basingstoke: Palgrave, 2005). R. Carr and B. W. Hart (Eds), The Foundations of the British Conservative Party (London: Bloomsbury, 2013).

${ }^{27}$ Also see K. Kowol, 'Renaissance on the Right? New Directions in the History of the Post-War Conservative Party', Twentieth Century British History, 27(2) (2016), pp. 297.

${ }^{28}$ Q. Hogg, The Case for Conservatism (Harmondsworth: Penguin, 1947), p. 13.

${ }^{29}$ Some accounts continue to regard non-doctrinaire conservatives as the most authentic representatives of its core ideas and beliefs. Consider, for instance, the tendency to contrast Thatcher's 'ideological' thought with the pragmatic moderation of her 'One Nation' colleagues. Here, the influence of Ian Gilmour's writing has been significant. I. Gilmour, Dancing with Dogma: Britain Under Thatcherism (London: Simon \& Schuster, 1992).

${ }^{30} \mathrm{R}$. Eccleshall suggested that Conservatism is an ideology concerned with the relations of power in society.

R. Eccleshall, 'The Doing of Conservatism', Journal of Political Ideologies, 5(3) (2000), pp. $275-87$.

${ }^{31}$ P. Clarke, Liberals and Social Democrats (Cambridge: Cambridge University Press, 1978). D. Blaazer, The Popular Front \& The Progressive Tradition (Cambridge: Cambridge University Press, 1992). B. Jackson, 'Socialism and the New Liberalism' in B. Jackson and M. Stears (Eds), Liberalism as Ideology (Oxford: OUP, 2012), pp. 35-50.

${ }^{32}$ B. Jackson, Equality and the British Left (Manchester: Manchester University Press, 2005)

${ }^{33}$ Some studies have, however, discussed the way in which Conservatives have represented their progressive opponents. See R. Saunders, 'Crisis? What crisis?': Thatcherism and the seventies' in B. Jackson and R. Saunders (Eds), Making Thatcher's Britain, op. cit, Ref. 10, pp. 25-42.

${ }^{34}$ Freeden, Ideologies, op. cit., Ref. 4, pp. 335-36. James Alexander, 'The Contradictions of Conservatism', Government and Opposition, 48(4) (2013), p. 603.

${ }^{35}$ One of the earliest articulations of this argument can be found in Mannheim's seminal study. K. Mannheim, Conservatism: A Contribution to the Sociology of Knowledge (London, 1986), p. 84.

${ }^{36}$ D. Clarke, The Conservative Faith in a Modern Age (London: CPC, 1947), pp. 12-13. Q. Hogg, The Case for Conservatism (Harmondsworth: Penguin, 1947), p. 24.

${ }^{37}$ C. A. R. Crosland, The Future of Socialism (London: Jonathan Cape, 1956), p. 314.

${ }^{38}$ R. Toye, 'The Labour party and Keynes', in E.H.H. Green and Duncan Tanner (eds.), The Strange Survival of Liberal England (Cambridge: Cambridge University Press, 2007), pp. 153-185. E.H.H. Green, 'The Conservative Party and Keynes' in Green and Tanner, The Strange Survival of Liberal England, pp. 186-211.

39 A. Seldon, 'Ideas are not Enough' in D. Marquand and A. Seldon (Eds), The Ideas That Shaped Post-War Britain (London: Fonatana, 1996), p. 289. For a discussion of these approaches, see A. Gamble, 'Ideas and Interests in British Economic Policy', Contemporary British History, 10(2) (1996), pp. 1-28.

${ }^{40}$ C. Hay, 'Ideas and the Construction of Interests', in D. Beland and R. H. Cox (eds.), Ideas and Politics in Social Science Research (Oxford: Oxford University Press, 2011), pp. 65-82. I. Budge, L. E. and M. D. Mcdonald, 'Ideology, Party Factionalism and Policy Change: An Integrated Dynamic Theory', British Journal of Political Science, 40(4) (2010), p. 803.

${ }^{41}$ For a summary of these approaches, see S. Berman, 'Ideational Theorizing in Political Science: The Evolution of the Field since Peter Hall's "Policy Paradigms, Social Learning and the State", Governance, 26(2) (2013), pp. 217-237.

${ }^{42}$ Hall, 'Policy paradigms, social learning and the state: the case of economic policymaking in Britain', p. 279.

${ }^{43}$ Gofas and Hay, 'Varieties of Ideational Explanation', op. cit., Ref. 7, p. 24.

${ }^{44}$ Freeden, 'The Stranger at the Feast', p. 29.

${ }^{45}$ Gofas and Hay, 'Varieties of Ideational Explanation', Ref. 7, p. 24.

46 Toye, 'The Labour party and Keynes', op. cit., Ref. 37, p. 185.

${ }^{47}$ See, for instance, Michael Oliver and Hugh Pemberton's illuminating analysis of Hall's model of policy change. M. Oliver and H. Pemberton, 'Learning and Change in Twentieth-Century British Economic Policy', Governance, 17(3) (2004), pp. 415-441.

${ }^{48}$ Paul Pierson, Politics in Time: History, Institutions and Social Analysis (Princeton: Princeton University Press, 2004).

${ }^{49}$ Ben Jackson, 'The Think-Tank Archipelago: Thatcherism and Neo-Liberalism' in Jackson and Saunders, Making Thatcher's Britain, op. cit., Ref. 10, pp. 43-61. 'Special Issue: Ideas and Think Tanks in Contemporary Britain', Contemporary British History, Vol. 10, Issues 1 and 2 (1996). A. C. Whipple, 'Speaking For Whom? The 1971 Festival of Light and the Search for the "Silent Majority", Contemporary British History, 24(3) (2010), p. 319-339. R. Middleton, 'Brittan on Britain: Decline, Declinism and the 'Traumas of the 1970s', in H. 
Pemberton, L. Black and P. Thane (Eds), Reassessing 1970s Britain (Manchester: Manchester University Press, 2013), pp. 69-95.

${ }^{50}$ P. Barberis, 'The Labour Party and Mr Keynes in the 1930s: A Partial Keynesian Revolution Without Keynes', Labour History Review, 71(2) (2006), pp. 145-166

${ }^{51}$ B. Jackson, 'Currents of Neo-Liberalism: British Political Ideologies and the New Right, c. 1955-1979', English Historical Review, 131(551) (2016), pp. 823-850.

${ }^{52}$ P. Norton and A. Aughey, Conservatives and Conservatism (London: Temple Smith, 1981), p. 50.

${ }^{53}$ Consider, for instance, R.H. Tawney and Michael Oakeshott.

${ }^{54}$ Jeremy Nuttall's innovative volume exposed the epistemology of the British Labour party, but its approach has not been employed by subsequent studies. J. Nuttall, Psychological Socialism (Manchester: Manchester University Press, 2006).

${ }^{55}$ B. Magee, The New Radicalism (London: St Martin's, 1962), p. 44.

${ }^{56}$ Freeden, 'Stanger at the Feast', op. cit., Ref. 1, p. 17.

57 The notion of a post-war settlement is, of course, highly contested. See P. Kerr, Postwar British Politics: From Conflict to Consensus (London: Routledge, 2001).

${ }^{58}$ Some historians of the nineteenth-century have begun to construct such conceptual histories. D. Craig and J. Thompson, (eds.), Languages of Politics in Nineteenth-Century Britain (Basingstoke: Palgrave, 2013).

${ }^{59}$ That is not so say, of course, that these categories are not observable in the discourses of political actors. See J. White, 'Left and right as political resources', Journal of Political Ideologies, 16(2) (2011), pp. 123-144.

${ }^{60}$ I. Crewe and A. King, The Birth, Life and Death of the Social Democratic Party (Oxford: Oxford University Press, 1995).

${ }^{61}$ Some historians of modern Britain have made engagements with this literature. See, for instance, E. Robinson, 'Defining Progressive Politics: Municipal Socialism and Anti-Socialism in Contestation, 1889-1939', Journal of the History of Ideas, 76(4) (2015), pp. 609-611.

${ }^{62}$ One exception is John Callaghan's study of European social democracy. J. Callaghan, The Retreat of Social Democracy (Manchester: Manchester University Press, 2000).

${ }^{63}$ J. Leader Maynard, 'A Map of the Field of Ideological Analysis', Journal of Political Ideologies, 18(3) (2013), pp. 299-327. 